\title{
FIDES QUAERENS IMAGINEM: THE QUEST FOR LITURGICAL REFRAMING
}

\author{
Johan Cilliers \\ Homiletics and Liturgy \\ Stellenbosch University
}

\begin{abstract}
This article proposes that the theory of reframing, as developed within the context of a philosophically based theory of change, and consequently adapted by psychologists and neurological change theorists, can be useful in the quest for liturgical renewal. It elucidates this theory from an aesthetical viewpoint, referring to art works by Duchamp, Dali, and Cilliers, and distinguishes between reframing as relabeling, re-figuring, and re-signifying. Some implications are drawn in view of liturgical reframing, implementing key concepts such as re-creation, repetition, the other and wise foolishness.
\end{abstract}

Key Words: Liturgy, Reframing, Aesthetics, Repetition, Recreation

\section{The Theory of Reframing}

The call for liturgical renewal is nothing new. The historical event of the Reformation, as well as the rise of the so-called Liturgical Movement of the $19^{\text {th }}$ and $20^{\text {th }}$ centuries could for instance also be described in terms of the need for liturgical renewal (cf. Wainwright 1978:37-38; White 1981; 43; Vrijlandt 1989:82-83). From a reformed perspective this need could be identified as an expression of a church that should constantly be in a process of (liturgical) renewal and reformation (ecclesia semper reformanda). The question of how this reformation or change should be brought about is, however, rather complex. It would seem that many attempts at liturgical renewal are nothing more than superficial reshuffling, or anxious efforts to retain dwindling church members, or simply a reflection of a marketdriven society and even principles of entertainment (Cilliers 2009:509-510).

Renewal implies change, but how does change take place? To answer this fundamental question, we need to revisit some theories of change. One theory that is of possible importance here is what has been called reframing. It was originally developed within the context of a philosophically based theory of change, and consequently adapted by psychologists and neurological change theorists (Capps 1990:3; cf. also Watzlawick et al. 1974:1-12).

In this theory, distinction is drawn between first and second-order change. Simply put, the former occurs within a given system (although the system as such remains unchanged), while the latter transforms the system itself. First-order change could be described metaphorically as events taking place within a dream, the structure or space of events being the dream itself, while second-order change takes place when the dreamer wakes up to a different state of consciousness, a different structure and space. It represents a shift in approach so that action is now applied to the proposed method of change, before addressing the problem as such (Watzlawick et al. 1974:11). Or in the words of Capps (1990:18): 
"Reframing challenges the assumption that the solution being employed is the solution, or would be the solution if only it could be performed better."

First-order change could in fact be analogous to the now famous saying: to reshuffle the chairs on the deck of the Titanic - it is superficial change that does not make a real difference to the inevitable outcome. Second-order change would here be not to try out a different technique of deck chair reshuffling, but rather to endeavour to repair the damaged hull! First-order change is 'more of the same', it is offering solutions which in themselves become, or at least, add to, the problem (Watzlawick et al. 1974:31). First-order change entails repetition of what is known within a system, perhaps even impressive or sensational repetition, but still merely repetition.

Second-order change does not normally happen by itself. It is rather "...introduced from the outside and therefore is not something familiar or something understandable in terms of the vicissitudes of first-order change, hence its puzzling, seemingly capricious nature" (Watzlawick et al. 1974:24). First-order change appears to be the normal ('common sense') way of going about things, while second-order change often seems weird, unexpected and paradoxical in nature. Therefore second-order change is often preceded by states of confusion and shock, by experiences of being in limbo (liminality).

Second-order change does not normally occur spontaneously because the frame in which we live is strongly woven; it does not change easily and can hold you prisoner. As a matter of fact, it is almost impossible to break free from it. If someone says: "I've been framed!" it expresses this sense of captivity, even of helplessness - in this case of an (unfair) frame that has been imposed on (or over) me. The question then is: how do we affect transformation (or reformation) to our frames; how do we move from first-order to second-order changes?

The abovementioned change theorists would say: in order for second-order change to be affected, reframing must take place. But what does reframing in fact entail? According to Watzlawick et al. (1974:95) it is "to change the conceptual and/or emotional setting or viewpoint in relation to which a situation is experienced and to place it in another frame which fits the 'facts' of the same concrete situation equally well or even better, and thereby changes its entire meaning" (cf. also Capps, 1990:17).

One of the goals of reframing is to "create new alternative behaviors" (Bandler and Grinder 1979:160). Reframing changes meaning, and changed meaning results in behavioral changes (Capps 1990:10). Bandler and Grinder - who were the first scholars to link the notion of reframing to their thesis of "neuro linguistic programming" - offer an extended definition of reframing. It is helpful to refer back to their original description of this concept:

Reframing is a specific way of contacting the portion or part - for lack of a better word of the person that is causing a certain behavior to occur, or that is preventing a certain other behavior from occurring. We do this so that we can find out what the secondary gain of the behavior is, and take care of that as an integral part of the process of inducing a change in that area of behavior... Reframing is a way of getting to say 'Hey, how else can I do this?' In a way it's the ultimate criticism of a human being, saying 'Stop and think about your behavior, and think about it in the following way: Do something new; what you're doing doesn't work! Tell yourself a story, and then come up with three other ways of telling the story, and suddenly you have differences in your behavior (Bandler and Grinder 1979:138, 183).

Within theology, this theory has been developed in terms of pastoral care by Donald Capps, but, to my knowledge, not yet in view of liturgy. This article is an attempt to do that. It is 
important to note beforehand, however, that 'reframing' is not something alien to the world of art. Perhaps reframing could even be called a (gentle) art, rather than a science although it is obviously not unscientific in nature (cf. Watzlawick et al. 1974:92). As a matter of fact, one could say that reframing is principally an aesthetical concept: it is not incidental that art works are normally framed, and as we shall consequently point out, indeed sometimes also reframed. In any case, (good) art seems always to reframe (dimensions of) life as such.

It is also a well-argued fact that there are fundamental structural coincidences between art and theology, and specifically liturgy (cf. Cilliers 2007:55-78). Liturgy is, or could be, an expression of a faith in search of images (fides quaerens imaginem), i.e. of an imaginative theology. This theology and liturgy could be called imaginative deciphering, or 'Sinndeutung.' (cf. Gräb 2006:29 f.; also 2006b:205 f.). This act of indicating and creating meaning has been called aesthetic reason or aesthetic hermeneutics (cf. Van Erp 2003:15; Cilliers 2009b:32-47; also Louw 2001:91 f.). In a sense reframing is fundamentally about this aesthetical (imaginative) re-creation of meaning. When we pursue the notion of liturgy as reframing, it therefore seems appropriate to take cognisance of the aesthetical dimension of reframing.

\section{The Aesthetical Dimension of Reframing}

We now turn to three examples or levels of aesthetical reframing. These three levels are actually intertwined and are separated here simply for the sake of discussion. They all imply change of that which exists, but without completely discarding the latter. All three therefore include the concept $r e$ - as already indicated in re-framing (in other words going back, in order to go forward; cf. also 3.1 below). The first is:

\section{Reframing as Re-naming (or: Re-labelling)}

The (in)famous art work of Marcel Duchamp, entitled Fountain (1917), could serve as an example. The work simply consists of a porcelain urinal, taken out of its customary setting and being placed in a new and unfamiliar one, namely an art gallery. Duchamp submitted Fountain under the pseudonym, 'R Mutt' as a type of prank, but also as a critique on some of the most basic conventions of (avant-garde) art. The organisers of the exhibition were furious - was the artist equating modern art with a toilet fixture? Fountain was promptly taken out of the exhibition and mysteriously 'disappeared' after that.

With this work Duchamp introduced the concept of 'ready-made' or 'found object' into the art world, and challenged traditional preconceptions of what art is, which is typical of the Dadaist art movement (cf. Adam and Cleave 1996:142). It is important to note that Duchamp did not alter the form of the art work (besides adding a date and fictitious name on the side; and significantly, turning it upside down), but that he has taken it out of its customary setting (frame), placed it within a new one and renaming (or: re-labeling) it. The urinal now becomes a fountain. Through this act of reframing, which includes renaming, the reframed and renamed object is given a new identity; it becomes a new 'reality'.

Duchamp defended the piece against charges that it was mere plagiarism, or a plain piece of plumbing. According to him the question was not whether 'Mr Mutt' created the fountain with his own hands or not. What was of importance was the fact that he in fact chose this object, taking it as an ordinary article of life, placing it so that its normal significance disappeared under the new title and point of view, and thus created a new meaning for that object. 


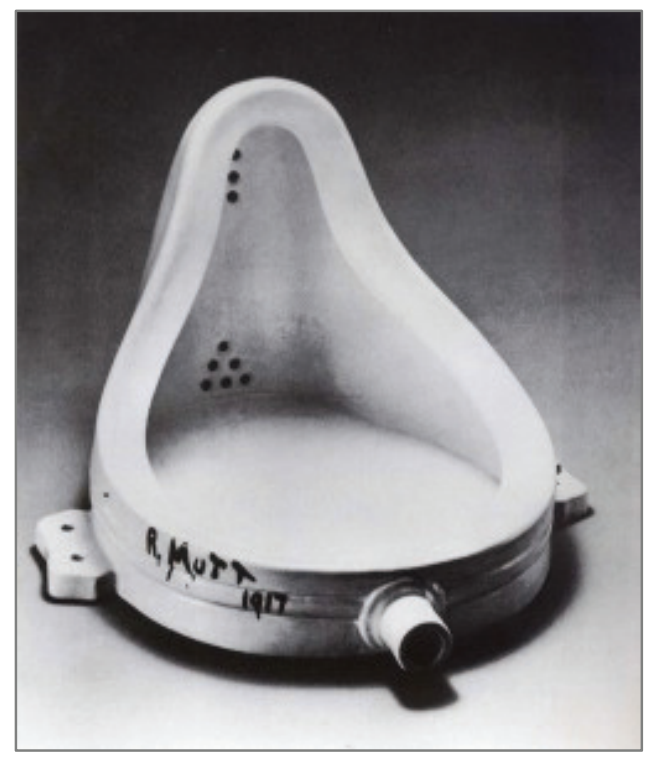

This art work exemplifies the fact that nothing is 'real' in itself, or could at best be described as adioforon (something without value as such, until evaluated - admittedly within and therefore bound to, one's own psychological, cultural and social frameworks). This is inter alia what Dadaism tried to achieve: to challenge the art world with its set beliefs about (the depiction of) reality. Duchamp's art work illustrates the fact that relabeling can in fact create (new) reality. In this case: a urinal is given a new name and 'becomes' a fountain! Could one say that it affects the way in which viewers could in future look at, and evaluate, both urinals and fountains?

\section{Reframing as re-figuring}

In the next example, taken from the surrealist art of Salvador Dali, the 'ready-made' object is a clock, also taken out of its usual setting, but here its form is also altered. Dali's clock remains recognisable as a clock, but it also takes on a new, quite surprising form.

Surrealism originated in post World War One France in the nineteen twenties, and its aim was to resolve the "previously contradictory conditions of dream and reality" (according to its main theorist, André Breton; Adam and Cleave, 1996:506). Surrealists painted unnerving and seemingly illogical scenes, often making use of collections or scenes from everyday life, allowing the unconscious to express itself (Berman, 1983:21). The surrealistic movement included renowned artists such as Bellmer, Brauner, Dali, Delvaux, Ernst, Kahlo, Gorky, Klee, Preller, and many others (Berman 1975:129).

Surrealism, like its forerunner, Dadaism, protested against the snobbery and traditionalism of the art establishment, and warned against a narcotic stupor within aesthetics. It strived to unmask kitsch. As such it represented a type of anti-art, for the sake of art (Bohren, 1980:60). It could indeed be described as a revolutionary art movement that often juxtaposed seemingly incongruent objects in order to create feelings of discomfort and even resistance from the viewers - feelings that could in turn lead to behavioural change. As such it rejected any form of (psychological or epistemological) 'norm', and rather encouraged an open process of re-discovery and indeed reframing. 


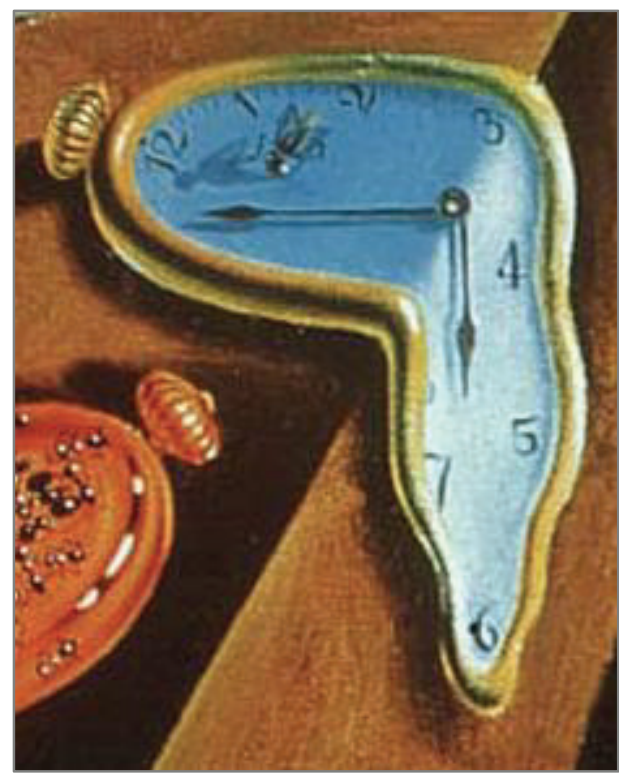

One of the best known surrealists would probably be Salvador Dali. His creation of a 'melted clock', as seen above (and being part of a larger painting, called The Persistence of Memory, or Melting Clocks; 1931), illustrates the intentions of surrealism in an evocative manner. Normally watches do not look like this. They are rather rigid objects, signifying that (our understanding of) time is set, and cannot be altered. Time cannot be bent - at least not in our earthly experience of it. Therefore we are victims of time; we are pulled along in its wake. Time waits for, or obeys no one. Tempus Fugit - time flies; constantly escaping from our grasp. It indeed seems as if time governs our lives, every minute detail of it, whether we accept it or not.

But Dali challenges us to revisit (reframe and refigure) our understanding of time. He reminds us that clocks are human inventions, and that we need not be victims of time. Time becomes pliable, and is no longer rigid or deterministic. Time opens up spaces for existence, and should not be seen as the enemy of existence. Time is a gift, not a threat. Dali's melted clock transposes us out of time to an experience in which time is no longer normative. We are invited - via imagination - into a radical different experience and completely new evaluation of time.

Whichever way one chooses to interpret Dali's melted clock, the point is clear: he invites us to reframe and refigure, to step into an alternative space of co-ordinates, to try out a different viewpoint. He subverts our conventional usage of watches and clocks. He says: take another look. Discern deeper and further - perhaps this will help you to come closer to a better, more humane view on time.

Perhaps we could say that the reframing of surrealist art consists of three stages. The first is position, or status quo (stasis); the second is questioning of this position, of alienating that which we thought we knew (anti-stasis); and the third the possibility of a reevaluation, and ultimately a reconfiguration of the original position, in other words a new position, surpassing the original (meta-stasis; cf. Adam and Cleave, 1996:506). 
I am not advocating here that all liturgists should become surrealists or Dadaists. Of course there were also flaws and excesses in this movement. It seemed to be strong in the area of anti-stasis, without really offering a meta-stasis, or at best an embryonic form thereof. But they, more than anyone else, understood the notion and need of reframing. In this sense they represent a valuable liturgical collaborator.

\section{Reframing as Re-signification}

In the next example, created by Johan Cilliers and entitled Interior of the Cross: Introspective Reflection (2009) ${ }^{1}$ a 'ready-made' object (a window frame) again makes its appearance. The art work actually consists of a wooden box, with a painted window at the back, revealing a tranquil, African scene, but also a real window at the front, through which the viewer is invited to look into the interior. Light falling through the window at the back is painted on the floor in the interior; but natural light also falls into the interior through the front window - creating subtle shadows of a cross, created by the cross-bars of the front window, and depending on the position in which the viewers are standing in front of the art work.

At first glance the window frames seem like just that: window frames. But closer scrutiny reveals that it is also taken out of its ordinary setting (like Duchamp's urinal), but in this case the form has not been altered dramatically (like in Dali's melted clock). Rather, subtle 'clues' or 'signs' are introduced which reframe the window frames to receive new identity and meaning: the shadow of a crucified figure on the inside (hanging from the 'cross' of the window; being part of the shadow falling on the floor), as well as the curtain bindings made of thorn branches, add new dimensions of meaning to the window frames.

Something quite 'ordinary' is reframed in terms of the Christ event; life - also the suffering of life, as embodied in the crucifixion - is now viewed in the light of the resurrection (literally shining through both the windows!). The curtain to the holiest inner sanctuary has been pulled away through the suffering of Christ (crown of thorns) and through these 'signs', as seen in the light of the crucifixion, life is re-signified as being holy. The 'interior of the cross' now glows in the light of the resurrection.

This re-signification also denotes a re-dignifying of life through subtle clues of God's presence in our world, one could say: through these footsteps of God (vestigiae dei) throughout our reality. The viewer looks into the 'interior of the cross' from both sides: through the painted window at the back, but also through the window in front. The viewer's vision is challenged; it implies: look again, look deeper. Life (the space between the two windows, i.e. the interior of the cross), is actually filled with the light of the resurrection, and the viewer's is given a new perspective through the lens of, and in the light of, this radical reframing-through-resurrection. 


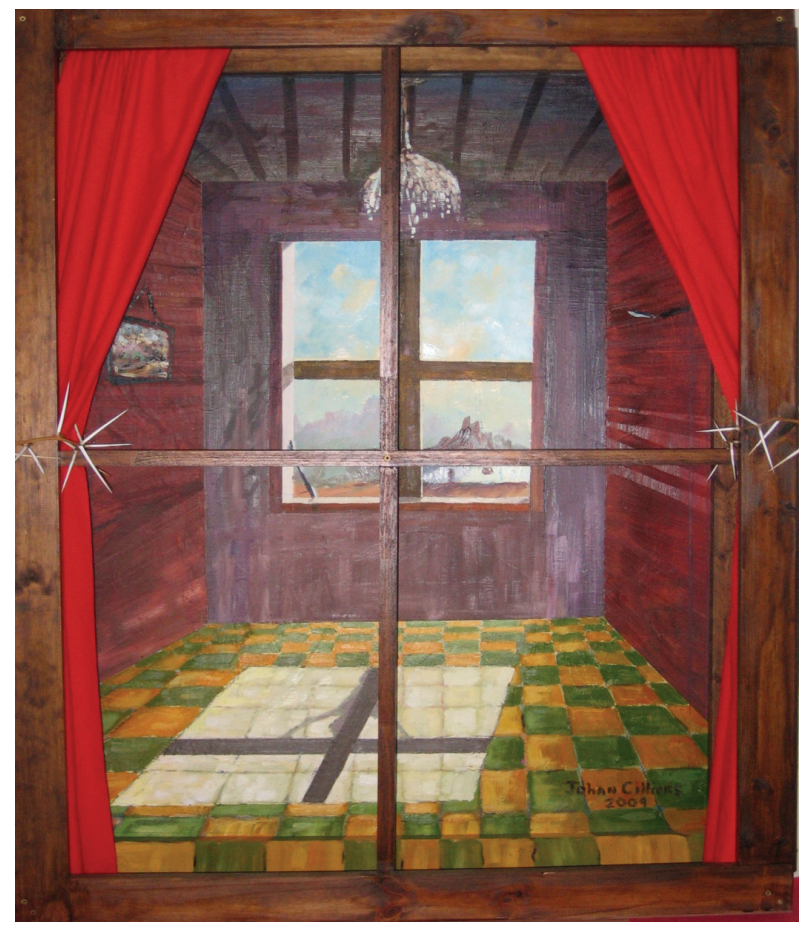

This process of re-signification (making abstract truths, in this case God's presence, real and tangible through signs) could indeed be called a 'benevolent sabotage' of reality - for the sake of reality (cf. Watzlawick et al. 1974:142-146). It does not seek 'solutions' within the frame that could in fact be the problem itself, but in 'signs of transcendence' from 'outside' - being brought to light, literally, through the resurrection. It is indeed an act of imaginative deciphering, an act of indicating and creating meaning. In this deciphering of life in the light of the resurrection lies the most profound reframing of all: between crucifixion and resurrection there exists no logical connection. The leap from crucifixion to resurrection is strange, surprising, puzzling and paradoxical and is not something dictated by logic. It reveals God's ultimate reframing of the 'problem' of life, i.e. death. Death is swallowed up in the reframing of the resurrection, i.e. Life (cf. 1 Cor 15:54, 55). The resurrection is reframing, par excellence.

Some liturgical implications of reframing now need to be elucidated. I restrict myself to four possible strands of thought.

\section{Liturgical Implications of Reframing}

\section{Liturgical Reframing as Re-creation}

As already mentioned above, the notion of reframing in fact implies a re-visitation of a given reality, as articulated in the prefix re. In all three of the art works referred to it is clear that the form as such was not rejected, but rather taken into re-consideration in a variety of ways. It is interesting to note that someone such as Moltmann (1969:32-33) sees the notion of $r e$ as ironical, even negative. According to him movements such as the renaissance and the reformation, as well as concepts like revolution, revival, renewal and restoration all 
re(!)veal a longing for a (golden) past, even a cyclical understanding of history. It represents change while 'dreaming backwards.' He rather opts for an embracement of the novum (completely new reality) instead of the old re. This prompts the question: should one rather speak of provolution, etc., and in this sense, also of proframing?

I am of the opinion that we need not necessarily choose between re and pro. They both form part and parcel of the art of reframing - as long as re does not denote a succumbing to first order changes (cf. further below in 3.2). The fact is: we need not re-invent liturgy, or re-discover the liturgical wheel. Liturgical traditions have been handed down through generations, and one could in fact say that these traditions all 'go back' to certain fundamental, Biblical understandings of worship. The core confession, 'Christ is Lord!' (cf. 1 Cor 12:3) for instance comes to mind, or the fourfold structure of early Christian worship gatherings, namely to listen to the teaching of the Apostles, to eat together, to experience koinonia and to pray (Acts 2:42). Reframing, in my opinion, actually re-stores the potential of the richness and variety of tradition to worship services that to a large extent have become a-historical. In this sense re means to 'go back' to liturgical tradition 'once again'. This does not mean that we perpetuate a meaningless repetition or maintenance of tradition, but in fact that we continuously probe into the fullness (pleroma) of God's fulfilled promises. The reformed notion of a church that must always be reformed (ecclesia semper reformanda) that we referred to earlier should be understood in this sense: not as a repetition for repetition's sake, but as a process through which we are constantly surprised and transformed by the fullness of God's fulfilled promises. But in order for this to happen, we do need to 'go back', we do need to re-member.

It would seem that the act of remembrance (anamnesis) is indeed of paramount importance for liturgical reframing. What we remember, but also how we remember, determines not only our liturgical experiences in the present, but also our hope for the future. The act of remembrance surpasses and condenses time and space. The past becomes present and simultaneously a component of the future. In this sense, we 'remember' a future for ourselves that exists in hope. In the present (moment of worship) we think, tell and act back (remember) towards the future (cf. Cilliers 2009:513). Both the re and the member are important: we go back to re-member, i.e. re-group and re-align with a view to the future.

\section{Liturgical Reframing: not 'More of the Same'}

But, having said 're' and 'once again' we must hasten to add: this does not mean 'more of the same'. As emphasised already: reframing is not equal to liturgical repetition or liturgical re-gurgitation. On the contrary: reframing implies dynamic processes like relabeling, re-visioning, re-aligning and re-imagining (cf. Capps 1990:4). Not 'more of the same', but rather alternatives, even paradoxes that challenge the existing to attain new meaning and therefore evoke behavioural change. ${ }^{2}$

Seen through a liturgical lens, the abovementioned aesthetical examples all indicate that (liturgical) renewal is comprised of much more than mere repetition (repetitio) of ecclesial

\footnotetext{
A classic Biblical example of this would be the way in which King Solomon "reframes" the situation when two women come to him with the dilemma of a dead baby (1 Kings 3:16-27). His command to cut the infant in two imparts new meaning to the life (and future) of the baby and this leads to (rather dramatic) behavioural changes in the attitudes of the two women. The Bible in fact teems with incidents that could be called reframing, for instance the parables told by Jesus and the way in which he interprets the Torah in the Sermon on the Mount (cf. Matt 5 to 7).
} 
tradition, or mere imitation (imitatio) of biblical truths, but rather change that in fact creates new 'realities'. It is re, but it is also creatio - in the strongest sense of the word. Through renaming, ${ }^{3}$ re-figuring and re-signifying new identity is created; i.e. second-order change is attained. Liturgically speaking, reframing would or could for instance not offer a theology of affluence, or escapist sentimentalism as 'solutions' to the problem of suffering (these tendencies in fact explain why lament is so frequently absent from our liturgies), as these represent first-order changes. It would rather go deeper, or in the imagery of the last mentioned art work, into the 'interior of the cross' - where the light of the resurrection denotes the most profound second order change - contra all logic and expectation.

Liturgy, and therefore liturgical renewal, is not (primarily) about being 'correct' according to church polity and ecclesial confession, but is rather about being changed at a deeper, second level. Liturgical renewal does not start or end with questions such as: when to stand and what to sing and how to re-arrange the décor. It is, once again, rather about finding new meaning that evokes behavioural change.

This of course prompts the question: how can new meaning, and therefore new behaviour, be found through reframing?

\section{Liturgical Reframing as Encounter with the 'Other'}

We have already mentioned the fact that according to some exponents of the theory of change it is only possible to achieve reframing, and therefore second-order change, through interruption from the 'outside'. Some theorists such as Bandler and Grinder take as point of departure the inherent ability of people to change their mind-sets themselves. Liturgically speaking, I would rather opt for the notion that change of mind (or frame) can only be initiated from the outside.

In terms of liturgy this would mean that the quest for renewal can also only be fostered when liturgy is interrupted by second-order change 'from the outside'. I alone or we as a group cannot do it. Paradigms (basic structures) can only be changed through, and together with the 'other'. Theologically speaking Christ (the Other) always comes with the other. A rather pertinent Biblical case of "reframing through the Other and therefore reframing the other" can be seen in the episode where Peter had his vision of even the "unholy animals' being sanctified through the Christ event (cf. Acts 10:1-48). Peter's paradigm (frame) was reframed by the so-called unholy other, but actually by the Other - and true change took place. This is indeed second-order change 'from the outside'.

We reiterate: second-order change cannot be achieved within the dynamics of the 'ingroup' alone. Even if the solutions that are presented within this group seem quite spectacular, or the exact opposite of that which exists (the so called enantiodromia, as Heraclites, the Philosopher of change, named it) - it still remains first-order change. ${ }^{4}$ The

3 There are of course many instances of renaming in the Bible. It starts out with the Genesis narrative, where reality (sun, moon, stars) are renamed as belonging to God, as being created by God and not by the gods. Reality is "created" in this manner, viewing it through the lens of Yahweh, the Creator. Even human beings receive the gift of (re)naming the animals, and so "creating" reality within the cosmos (cf. Gen. 2:18-19). Theologically speaking, through the Christ event, God's people are renamed: they are now called Christians (cf. Acts 11:26). Within the theory of change, this affirmation of the others (new) worth, i.e. granted dignity, has been called the Bellac Ploy: the affirmation of renaming indicates, but also creates the dignity as such (cf. Watzlawick et al. 1974:131-133).

$4 \quad$ Politically speaking a dictator that takes the place of another dictator still remains a dictator, even though his or her "policies" might seem to be direct opposites. He or she still operates within the realm of first-order change. Contrary to this, the remarkable way in which someone like Nelson Mandela reframed the politics of revenge (a tooth for a tooth) into embodied reconciliation denotes true second-order change. 
structure of the group must be changed, must be bent out of its proportions - almost like Dali's melted clock - in order to attain new meaning and therefore new behaviour.

In the light of this theory of change, could one venture to say that true liturgical renewal within the Dutch Reformed Family of Churches in South Africa can only be brought about when at least the members of this family encounter one another also within a liturgical setting? Can second-order change only become a reality when the 'other' enters 'my' and 'our' space, and it is no longer a question of 'we' and 'them'? Will this 'melted clock' transformation not introduce a new time, indeed a 'kairos time' for the church in South Africa? Or will the (separated) liturgical worlds keep on reshuffling the chairs on the liturgical deck of a sinking ship?

But, meeting the 'other' within the same family could still easily add up to 'more of the same', and consequently liturgical restoration. Should our understanding of the 'other' not be broadened even further? Should our liturgies not become more exposed to the marginalised and often silenced 'other'? How can deep, second order change be brought about in our liturgies without facing the poor, the ostracised, the downtrodden - exactly those people whom Christ associated with? Levinas has reminded us that: “... the epiphany of the face qua face opens humanity. The face in its nakedness as a face presents to me the destitution of the poor one and the stranger..." (Levinas 1969:213). Are we content with liturgical regurgitation, or are we feeding the poor?

\section{Liturgical Reframing as 'Wise Foolishness'}

The interruption by the other is often, as already noted, weird, unexpected and paradoxical in nature. It is, however, not the intention of reframing to change circumstances through force or manipulation or as a 'hostile take-over'. These forms of 'change' in fact normally do not endure.

Reframing does not operate in a sensational manner or through power or enforcement; it is rather playful, humorous and has what one could call a certain foolishness to it. It has been well documented that many oppressive systems have for instance been relativised and ultimately transformed not through violent resistance but rather through laughter as ethical resistance and as creative response to the problem of evil (cf. Bussie 2007:32 ff.). The remarkable fact is that reframing as wisdom-turned-upside-down (as exemplified in Paul's 'reframing' of wisdom and foolishness in 1 Cor 1:18-31), could indeed be linked together structurally. Or as Capps puts it: "Reframing is the very lifeblood of wise-fool ministry." (1990:169 cf. also 169-181; also Alastair Campbell 1981:47-64).

The turned-upside-down-urinal of Duchamp could be described as funny or foolish. And yet it exerts a strange 'power' and an unmistakable attraction. It invites you to rethink, but in a playful manner. Indeed:

Lightness of touch and the releasing power of laughter are essential to the art of reframing. Otherwise, the art degenerates into a weapon which manipulates and mocks the very ones it means to help, and dehumanises those who use it. Reframing is not for angry prophets, but for prophets who know the releasing power of laughter. Reframing is for prophets who are wise enough to know that God can get al.ong perfectly well without them, and fool enough to believe that God would never try to go it alone (Capps 1990:180).

Liturgical reframing should not force the 'signs' of God's immanence upon people. The footsteps (vestigia dei) of God in this world are not thunderous giant's stompings. On the contrary, it could be overlooked and not heard. Liturgical reframing helps to identify these 
signs, and reframe reality - like Joseph did in his description of the events that took him out of his father's house and into Egypt. He informs his brothers after the reunion: "I am your brother Joseph, whom you sold into Egypt. Now do not be upset or blame yourselves because you sold me here. It was really God who sent me ahead of you to save people's lives." (Gen 45:4, 5). Reframing here lies in the remarkable re-interpretation or theological relabeling of the events: "It was really God..."

For some this type of interpretation could indeed sound foolish, even absurd. But it is wise foolishness, absurd relabeling - that truly changes reality. It celebrates the most profound reframing possible: by God Himself.

\section{BIBLIOGRAPHY}

Adam, CV, SS Cleave 1996. The Art Book. London: Phaidon.

Bandler, R, Grinder, J 1979. Frogs into Princes. Neuro Linguistic Programming. JO Stevens (ed.) 1975. Moab, Utah: Real People Press.

Berman, E 1975. The Story of South African Painting. Cape Town and Rotterdam:

AA Balkema.

Berman, E 1983. Art and Artists of South Africa. An illustrated biographical dictionary and historical survey of painters, sculptors and graphic artists since 1875.

Cape Town and Rotterdam: AA Balkema.

Bohren, R 1980. Predigtlehre. München: Kaiser.

Bussie, JA 2007. The Laughter of the Oppressed. Ethical and Theological Resistance in Wiesel, Morrison, and Endo. New York: T\&T Clark.

Campbell, A 1981. Rediscovering Pastoral Care. Westminster Press.

Capps, D 1990. Reframing. A new Method in Pastoral Care. Minneapolis: Augsburg Fortress.

Cilliers, JH 2007. Binne die kring-dans van die kuns. Die betekenis van estetika vir die gereformeerde liturgie. Stellenbosch: Sun Press.

Cilliers, JH 2009. As it is in heaven? Reflections on liturgical reframing. Scriptura. International Journal of Bible, Religion and Theology in Southern Africa. 102 (3):509-517.

Cilliers, JH 2009b. The Beauty of Imagined Meaning: Profiling Practical-Theological Aesthetics. Praktiese Teologie in Suid-Afrika. 24 (1):32-47.

Gräb, W 2006. Religion als Deutung des Lebens. Perspektiven einer Praktischen Theologie gelebter Religion. München: Gütersloher Verlagshaus.

Gräb, W 2006b. Sinnfragen. Transformationen des Religiösen in der modernen Kultur. München: Gütersloher Verlagshaus.

Levinas, E 1969. Totality and Infinity. An Essay on Exteriority. Translated by Alphonso Lingis. Pittsburgh, Pennsylvania: Duquesne University Press.

Louw, DJ 2001. Creative hope and imagination in a Practical Theology of aesthetic (artistic) reason. 4th International Academy of Practical Theology. Quebec International Conference, Canada, 14-20 May 1999. In: Paul Ballard \& Pam 
Couture (eds.), Creativity, imagination and criticism: the expressive dimension in Practical Theology. Cardiff: Cardiff Academic Press, 91-104.

Moltmann, J 1969. Geloof in de toekomst. Utrecht: Ambo.

Van Erp, S 2003. Fides quaerens imaginem. Esthetica als fundamentele theologie: geloof op zoek naar beelden. In: Tijdschrift voor Theologie 43, 15-39.

Vrijlandt, MA 1989. Liturgiek. 's-Gravenhage: Meinema.

Wainwright, G 1978. The Periods of Liturgical History. The Study of Liturgy. Ed. C Jones, G Wainwright, E Yarnold. London: SPCK. 33-38.

Watzlawick, P, Weakland, JH, Fisch, R 1974. Change. Principles of Problem Formation and Problem Solution. New York/ London: WW Norton.

White, JF 1981. Introduction to Christian Worship. Nashville: Abingdon. 